and health of children, complementary to the study of the maternity services published early in the year, is of renewed interest in view of the food situation and the National Health. Service Bill. Pointing out that the primary responsibility for bringing up healthy children must rest on the care and wisdom of their parents, the broadsheet emphasizes that if the retreat from parenthood is to be arrested, the skilled services and economic aid required to restore Britain's greatest and most neglected productive activity - parenthood - must be provided readily and without stint. Present divisions of the welfare and school medical services militate against continuity of medical care for the individual child, and its critical analysis of the present and future services leads P.E.P. to stress that in the nutritional field the greatest need is to implement fully the powers and duties that already exist, while the first need for the child health services is for co-ordination. Co-operation between health visitor and general practitioner, medical officer and children's physician is made difficult by the present administrative arrangements. Secondly, a medical service for children should be fundamentally a health service rather than a sickness service. The health services should study normal growth and development, about which too little is known, and the broadsheet strongly emphasizes the importance of research. Without a high standard of medical teaching and much extended research on such problems as breast-feeding, nutrition, physical education, the influence of social factors on child health, and on all the aspects of normal growth, the best organised medical service can do. little. With the proposed organisation of the hospital services in university regions, the future institutes of child health should be able to extend their influence beyond the immediate confines of the teaching centre and raise the standard of all child health services in the region. 6/6

\section{The National Grid of the Ordnance Survey}

THe Departmenal Committee appointed in 1935 by the Ministe of Agriculture and Fisheries to consider Ordints Survey plans and maps recommended that the Ifre-scale plans of Great Britain should be re-fs national sheet lines and that a national grid with the metre as unit, should be superimposed on all large-scale plans and most of the small-scale maps. The recommendation compels the use of a projection that will not introduce unacceptable distortions, on any of the scales, when it is extended over an area the size of Great Britain. Accordingly an orthomorphic projection, known as the Transverse Mercator, with its origin at lat. $49^{\circ} \mathrm{N}$., long. $2^{\circ} \mathrm{W}$., has now been adopted as the national projection for general use over Great Britain. When rectangular co-ordinates are referred to this origin, the easting co-ordinates of points to the west of the central meridian are negative, and the northing co-ordinates, though all positive, become inconveniently large for points in northern Scotland. To avoid these difficulties, $400 \mathrm{~km}$. have been added to all easting co-ordinates and $100 \mathrm{~km}$. subtracted from all northing co-ordinates. This places the working position of the origin a little to the south-west of Lands End and ensures that the co-ordinates of all points on the mainland of Great Britain are positive and less than $1,000 \mathrm{~km}$.

The Ordnance Survey has now issued a pamphlet (Booklet No. 1/45, "A Brief Description of the National Grid and Reference System", H.M.
Stationery Office, 1946. 4d. net) which briefly describes the geodetic and mapping situation in Great Britain at the time the Committee was appointed, and the steps taken to implement its recommendations. It then details a method of giving the grid reference of any point on maps and plans of all scales. This pamphlet will be of the greatest value to all map users, and to students of geography in particular, for whom the national grid will provide a most convenient aid for the recording of positions and statistical information.

\section{Work of Cultural Missions}

WHETHER as regards its origin, its immediate significance, or it promise for the future, Bulletin 1945, No. 11, of he Federal Security Agency (U.S. Office of entitled "Report on the Cultural Missiof 16 flexico" is a noteworthy report. Its subiacts the mission work done by a band of enthusias is and patient Mexicans among the Indians in theil remote villages. A preface written by Mr. J. W. Studebaker, U.S. Commissioner of Education, reveals that in September 1943 he had the opportunity of meeting the writer of the report and of visiting with him a group of Indian villages in which one of the missions was functioning. The report was thereupon written by the chief of the missions department, and here is the English translation. The work being done, says Mr. Studebaker, was an inspiration to him as an educator and as a citizen of a neighbouring country. The broad educational objectives, he proceeds, and the methods employed in this project for teaching Indian people a better way of life give confidence and inspire one with the belief that an isolated and somewhat estranged people of a great land will, through these means, be prepared for modern life and brought into the fold of genuine citizenship. Mr. Studebaker's closing words strike one as most remarkable. It is hoped, he says, that this report will contribute to a greater understanding of the important educational accomplishments "of our nearest southern neighbour, and that it will constitute an inspiration and a challenge to the educators of the United States". Following the report itself, a number of interesting and informative photographs, supplied by the author of the report, are added. Further, in order that the reader may secure more. information concerning cultural missions in Mexico, either from English or from Spanish sources, a list of related readings, prepared in the Division of International Educational Relations, is included.

\section{Fuel Economy in the United States since 1939}

The United-states National Committee of the World Pew Conference (Central Office, 36 Kingswa. Ldewon, W.C.2) has issued a report on that coutry's reactions to war conditions. Economy of fuel tas necessary, but in ways which differ from those 1 xperienced in Britain. Since hostilities ceased, except for temporary effects, such as labour troubles, difficulties have disappeared and efforts to save fuel are based on economies rather than availability of supplies. During the War, production suffered from labour troubles and especially transportation problems. This led to an increase in the use of hydrogenerated electricity from $\mathbf{4 4}$ to 80 billion $\mathrm{kWh}$. Attempts were made to increase production-by technical devices in the case of liquid and gaseous fuels. In coal production, major developments were "salvaging coal formerly rejected", which recalls British use of 'outcrop coal' and 'washery slurries'. 
Alternative fuels such as 'coal oil' mixtures were tried but not used extensively. Contrary to present British practice, the principal change was from oilfiring to coal-fired equipment, and in household use from oil to gas. There were control organisationsa petroleum administrator and a 'solid fuel administrator', and as civilian fuel became short, rationing was developed. Judged by British standards, the measures adopted do not sound onerous. For example, the general consumer would experience a restriction of solid fuels to seven-eighths of normal use. Various steps to conserve fuel were enforced, such as the adoption of 'brownout' and 'dimout' rules, reduction of space heating and organisation of a fuel economy campaign.

Post-war conditions are expected to bring more efficient equipment in domestic practice. Where hydro-electric power is available, and off-peak current can be used to store heat, there will be more spaceheating by electricity. No great reduction of fuel consumption is anticipated, however, in view of the increased demand for improved amenities. No radical improvements in conventional equipment are ex. pected. New designs include the gas turbine, hot-air turbine and the heat pump for cooling and heating. The War has compelled increased interest in fuel education-enforced by the "advent of shortages and increases in the relative costs of fuel". In this respect conditions resemble those in Britain.

\section{Abnormal Solar Radiation on 75 Megacycles}

Messrs. S. E. Williams and P. Hands, of the Department of Physies, University of Western Australia, hay sent a long communication referring to observatjons made there of 'solar radio-frequency radiation $h$ a wave-length of 4 metres, using a Yagi aerial of moderate directivity, mounted on a polar axis. Measurements of the ratio of currents due to solar plus-receiver noise and receiver noise only, recorded with the dipole short-circuited, were made with a milliammeter in the anode circuit of the (linear) second detector. Later an oscillograph was used to secure a continuous record. Continuous observations were maintained for from three to five hours each day, during the passage of the large sunspot group having mean meridian passage on July $26 \cdot 7$ (G.M.T.) and the two following groups with mean meridian passage on August 2.4. On the basis of these observa. tions they divide solar radio-frequency noise roughly into two components, one 'steady' or relatively slowly variable (Component I), the other abruptly variable (Component II). A striking example of the variation of the so-called Component II was observed on August 2, when it was estimated that this 'storm' involved changes in noise emission by 50-100 times in a few seconds.

These short-period variations during $03 \mathrm{~h} .14 \mathrm{~m} .10 \mathrm{~s} .-$ 03h. $29 \mathrm{~m}$. 10s. (approx. G.M.T.) corresponded with visual changes on the sun's disk as recorded on spectrohelioscope observations made by Watheroo Magnetic Observatory. A similar but less intense disturbance, during which the milliammeter showed increases in solar/receiver noise from 10 per cent to more than 150 per cent, was recorded on the same day between $04 \mathrm{~h} .51 \mathrm{~m}$. and $04 \mathrm{~h} .57 \mathrm{~m} .30 \mathrm{~s}$. (G.M.T.), when ionospheric equipment at Watheroo recorded a fade-out of intensity 4 (scale 1-9) during $04 \mathrm{~h} .45 \mathrm{~m} .-$ $05 \mathrm{~h} .00 \mathrm{~m}$., followed by a spectrohelioscope report of a faint prominence at $05 \mathrm{~h}$., indicating a flare at about 04h. $50 \mathrm{~m}$.
Messrs. Williams and Hands point out that since $75 \mathrm{mc} . / \mathrm{s}$. radiation cannot penetrate regions where the electron density is greater than $10^{8} /$ c.c., which would be exceeded in the lower chromosphere, the correlation of solar noise generation with prominence aetivity seems probable. Further, as disturbances involving the emission of Component II are not necessarily accompanied by fade-outs, whereas chromospheric flares occurring within an hour or so of local apparent noon almost always produce fade-out effects, they suggest that correlation of Component II with flares would not be generally observed, but that coincidences between these phenomena would depend on the level at which increased excitation of the $H \alpha$ line occurs. This note of work at the University of Western Australia should be read in conjunction with the communication by Dr. A. C. B. Lovell and C. J. Banwell on p. 517 of this issue of Nature.

\section{Survey of British Somaliland}

SugGesmons for a general survey of British Somaljand te made before the War in connexion with filty upplies, soil erosion and other problems AT cting theneral development of the country, but wo $\mathrm{N}$ t put into execution at the time. The Military Gpvernment of the Protectorate has now issued a report outlining surveys made and data collected from 1942 onwards, and recording the work of a special department under Major J. A. Hunt from its inception in August 1943 until December 1944 (Report on General Survey of British Somaliland, 1944. Pp. $12+17$ charts. (Burao: Gov. Press, 1946.) 3s. 6d.). The programme of work of the department conforms roughly to that advocated by Dr. E. B. Worthington in "Science in Africa", and starts with the accurate collection of meteorological and geological data, followed by a soil survey, plant and then animal ecology. The preliminary results are illustrated in a series of maps and diagrams published with the report, covering rainfall, plant ecology and tribal migrations and potential developments in minerals, water, agriculture and roads. The General Survey has now been recognized in principle by the Colonial Office, and funds have been provided under the Colonial Development and Welfare Act to finance an "economic survey and reconnaissance" with a programme extending until 1950. The water and mineral surveys will be made by two specialist geolog. ists. on arrival and may take up to two years. Altitude, rainfall and plant ecology are closely interrelated, and rain crop cultivation can only be considered and tested in a limited area above $4,000 \mathrm{ft}$. Sites are recommended for irrigation gardens and date plantations, and a new road from Berbera to El Afwein and Hudun is recommended as being situated on the most direct route to the eastern part of the Protectorate with no difficult escarpments to surmount. The Military Governor points out in his introduction to the report that the political and economic life of the Protectorate and neighbouring countries is threatened by increasing migrations of Somali tribes, who will be unable to find subsistence in their own country if conditions continue to deteriorate. The report strongly recommends publication of reports and specialist papers to stimulate interest in research, and also that when the two years survey of water and minerals has been carried out, the sharvey should organise a technical library and laboratory in Burao, which is the natural centre for any scientific work in the Protectorate. 